\title{
Heme 0xygenase 1 Up-Regulates Glomerular Decay Accelerating Factor Expression and Minimizes Complement Deposition and Injury
}

\author{
Maria G. Detsika, ${ }^{*}$ Pu Duann, ${ }^{\dagger}$ Vassilios Atsaves, ${ }^{\star}$ Apostolos Papalois, ${ }^{\ddagger}$ and Elias A. Lianos ${ }^{\star \dagger}$
}

\begin{abstract}
From the First Department of Critical Care Medicine \& Pulmonary Services, * Evangelismos Hospital, National and Kapodistrian University School of Medicine, Athens, Greece; the Division of Nephrology, ${ }^{\dagger}$ Department of Medicine, Robert Wood Johnson Medical School, Rutgers Biomedical and Health Sciences, Rutgers, The State University of New Jersey, New Brunswick, New Jersey; and the Research and Experimental Centre, ${ }^{\ddagger}$ ELPEN Pharmaceuticals, Athens, Greece
\end{abstract}

Accepted for publication July 11, 2016.

Address correspondence to Maria G. Detsika, Ph.D., 3 Ploutarchou St., Athens 10675, Greece. E-mail: mdetsika@ med.uoa.gr.

\begin{abstract}
Complement-activation controllers, including decay accelerating factor (DAF), are gaining emphasis as they minimize injury in various dysregulated complement-activation disorders, including glomerulopathies. Heme oxygenase (HO)-1 overexpression or induction has been shown to attenuate injury in complement-dependent models of glomerulonephritis. This study investigated whether up-regulation of DAF by heme oxygenase 1 (HO-1) is an underlying mechanism by using Hmox-1-deficient rats $\left(\right.$ Hmox $\left.^{+/-} ; H_{\operatorname{mox}}{ }^{-/-}\right)$or rats with H0-1 overexpression targeted to glomerular epithelial cells $\left(\mathrm{GEC} \mathrm{CH}^{\mathrm{H}-1}\right.$ ), which are particularly vulnerable to complement-mediated injury owing to their terminally differentiated nature. Constitutively expressed DAF was decreased in glomeruli of $H \operatorname{mox} 1^{-1-}$ rats and augmented in glomeruli of $\mathrm{GEC}^{\mathrm{HO}-1}$ rats. In $\mathrm{GEC}^{\mathrm{HO}-1}$ rats with anti-glomerular basement membrane antibody mediated, complement-dependent injury, complement component C3 fragment b (C3b) deposition was reduced, whereas proteinuria was diminished. In glomeruli of wild-type rats, the natural Hmox substrate, hemin, induced glomerular DAF. This effect was attenuated in glomeruli of $\mathrm{Hmox}^{-1-}$ rats and augmented in glomeruli of $\mathrm{GEC}^{\mathrm{HO}-1}$ rats. Hemin analogues differing in either metal or porphyrin ring functionalities, acting as competitive Hmox-substrate inhibitors, also increased glomerular DAF and reduced C3b deposition after spontaneous complement activation. In the presence of a DAFblocking antibody, the reduction in C3b deposition was reversed. These observations establish H0-1 as a physiologic regulator of glomerular DAF and identify hemin analogues as inducers of functional glomerular DAF able to minimize C3b deposition. (Am J Pathol 2016, 186: 2833-2845; http:// dx.doi.org/10.1016/j.ajpath.2016.07.009)
\end{abstract}

Dysregulated complement activation has recently gained emphasis as an underlying mechanism of various immunemediated forms of glomerular injury, including the recently characterized complement component C3 (C3) glomerulopathy. ${ }^{1}$ This putative mechanism increases the significance of complement-activation controllers, including decay accelerating factor (DAF), as potential therapeutic targets to achieve attenuation of complement-mediated injury.

DAF has been shown to minimize complement activation on both human and rat glomerular epithelial cells (GECs), as its inhibition increased complement-mediated cytotoxicity after sensitization with a complement-fixing antibody. ${ }^{2}$ In two independent studies using DAF-deficient mice with anti-glomerular basement membrane (GBM) antibody-mediated or immune complex-mediated

Supported by national funds from the European Union (European Social Fund) and Greece through the Education and Lifelong Learning operational program of the National Strategic Reference Framework Research Funding Program-Aristeia I (E.A.L.), and supported by a scholarship from ELPEN Pharmaceuticals Research and Experimental Centre (M.G.D.).

Disclosures: None declared.

Current address of P.D., Department of Internal MedicineCardiovascular Medicine, The Ohio State University, Columbus, $\mathrm{OH}$. 
glomerulonephritis, severe podocyte damage with proteinuria and increased C3 deposition occurred, while no difference in the expression level of complement receptor 1-related protein Y or CD59 was observed on leukocytes or in kidney tissue, thus implicating DAF as an important defense molecule against complement-mediated glomerular injury. 3,4

These findings were further confirmed in a mouse model of immune complex glomerulonephritis associated with marked C3 deposition in glomeruli. DAF-deficient mice had an increased prevalence of glomerulonephritis associated with significantly increased glomerular C3 deposition relative to wild-type (WT) controls. In contrast, disease expression in CD59-deficient mice was no different from that in WT controls. ${ }^{5}$ Collectively, these observations support the important role of DAF in protecting against complement-mediated glomerular injury.

In the anti-GBM antibody-mediated, complementdependent model of injury, we previously reported that heme oxygenase (Hmox)-1 induction in glomeruli after exogenous administration of the natural Hmox substrate/ inducer, hemin, or GEC-targeted $\mathrm{HO}-1$ overexpression $\left(\mathrm{GEC}^{\mathrm{HO}-1}\right)$ in mice minimized extent of injury. ${ }^{6,7}$ However, the underlying mechanisms were not explored. It was recently reported that, in cultured endothelial cells derived from Hmox-1-deficient mice, DAF expression was reduced. ${ }^{8}$ This finding points to heme oxygenase 1 (HO-1) as a putative regulator of DAF and raises the question of whether the protective effect of $\mathrm{HO}-1$ in complementdependent forms of glomerular injury involves DAF upregulation.

To address this question, we generated two novel rat models: Hmox-1-depleted rats, and $\mathrm{GEC}^{\mathrm{HO}-1}$ rats, which are the only cell type expressing DAF in the rat nephron. ${ }^{9}$

\section{Materials and Methods}

\section{Reagents}

Anti-Hmox-1 polyclonal antibody was purchased from Enzo Life Sciences (New York, NY). Anti-DAF antibody clone RDII-24 was a kind gift from Prof P. Morgan (University of Cardiff, Cardiff, UK), and clone RDIII-7 was purchased from Hycult (Uden, the Netherlands). Antirat $\mathrm{C} 3 / \mathrm{C} 3$ fragment $\mathrm{b}(\mathrm{C} 3 \mathrm{~b})$ antibody was purchased from Hycult; anti- $\beta$-actin antibody, from Sigma-Aldrich (St. Louis, MO); and anti-glyceraldehyde-3-phosphate dehydrogenase antibody, from Cell Signaling Technology (Danvers, MA). Hemin, cobalt protoporphyrin, zinc protoporphyrin, protoporphyrin IX (PPIX), cycloheximide (CHX), and phosphatidylinositol-specific phospholipase C were purchased from Sigma-Aldrich. Tin protoporphyrin and tin mesoporphyrin (SnMP) were purchased from Tocris Bioscience (Bristol, UK). A deglycosylation kit was purchased from CalBiochem (EMD Millipore, Billerica, MA).
Animals

Adult male Sprague-Dawley rats, $300 \mathrm{~g}$ in body weight, were used in this study. Animals were reared in accordance with the European Union Directive for the care and use of laboratory animals, and all procedures were approved by the Hellenic Veterinary Administration and the ethics committee of Evangelismos Hospital (Paphos, Cyprus). For the generation of transgenic rats, all procedures described were conducted according to the NIH's Guide for the Care and Use of Laboratory Animals. ${ }^{10}$

\section{Generation of $H \operatorname{mox} 1^{+/-}$and $H \operatorname{mox} 1^{-/-}$Rats by ZFN-Mediated Hmox1 Gene Disruption}

Zinc finger nuclease (ZFN) constructs targeting the rat Hmox-1 sequence 5'-GGTGGCCCACGCATATACCCGCTACCTGGGTGACCTCTCAG-3' within exon 3 (Table 1) were designed and assembled in a ready-to-inject mRNA format by Sigma-Aldrich. The underlined sequences are recognized by the right and left ZFNs, respectively (on opposite strands), and are separated by the lowercase 7-bp spacer sequences, where the nuclease domains interact to cause a double-strand break. mRNA at a concentration of 2 $\mathrm{ng} / \mu \mathrm{L}$ was introduced by male pronuclear microinjection into Sprague-Dawley rat embryos, and surviving founder generation pups were screened using a CEL-I nuclease assay as previously described. ${ }^{11}$ A total of 149 fertilized oocytes were microinjected, and 78 surviving embryos were kept for implantation into the oviducts of pseudopregnant female Sprague-Dawley rats and allowed to go to term. Nineteen pups were born, among which 18 could be screened for ZFN-mediated disruption of the Hmox$1-$ coding sequence. Screening to verify disruption of the ZFN target site was performed by standard PCR amplification of DNA prepared from rat tissue (ear or tail). PCR primers sequences were: forward, 5'-ATGCCCCACTCTACTTCCCT-3'; reverse, 5'-TTCATGCGAGCACGATAGAG- $3^{\prime}$.

Two founders were identified (Supplemental Figure S1), one of which was mosaic and harbored Hmox-1 mutant alleles 1 and 2. Hmox-1 mutant allele 1 was a 16-bp frameshift deletion in the Hmox-1 exon 3 coding sequence, overlapping the ZFN target site. Hmox-1 mutant allele 2 was a 21-bp inframe deletion associated with a 3-bp insertion "ggg," resulting in a net loss of $18 \mathrm{bp}$ and maintaining the open reading frame of Hmox-1. A litter of pups was obtained, suggesting that the disruption of Hmox-1 in the Sprague-Dawley rat can be tolerated. The second founder was apparently heterozygous for a single mutation, Hmox-1 mutant allele 3, a 10-bp frameshift deletion, in Hmox-1 exon 3. While rats with biallelic Hmox-1 gene disruption were short-lived and developed various anomalies, hemizygotes survived to breeding age and were apparently healthy and reproductively fit.

The WT allele was $340 \mathrm{bp}$; the mutant allele 1, $324 \mathrm{bp}$; the mutant allele 2, $322 \mathrm{bp}$; and the mutant allele 3, $330 \mathrm{bp}$. 
Table 1 Target DNA Sequences of the Hmox1 Gene ORF (Exon 3) to Which the Designed ZFN Pairs Bind

\begin{tabular}{|c|c|c|}
\hline ZNF pair \# & Position & Sequence \\
\hline \#06 & $3507-3515$ & 5'-GGCCTCCTTGTACCATATCTATACGGCCCTGGAAGAG-3' \\
\hline \#07 & $3514-3521$ & 5'-СTCСТTGTACСАТАTCTATACGGCCCTGGAAGAGGAG-3' \\
\hline \#08 & $3580-3587$ & 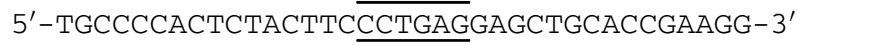 \\
\hline$\# 09$ & 3583-3589 & 5'-CCACTCTACTTCCCTGAGGAGCTGCACCGAAGGGCTGCC-3' \\
\hline \#10 & $3590-3597$ & 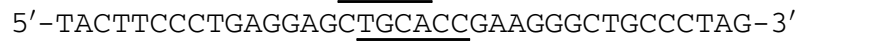 \\
\hline \#11 & $3628-3634$ & 5'-CAGGACATGGCCTTCTGGTATGGGCCCCACTGGCAGGA-3' \\
\hline \#14 & $3750-3756$ & 5'-CCACGCATATACCCGCTACCTGGGTGACCTCTCAG-3' \\
\hline \#15 & $3754-3762$ & 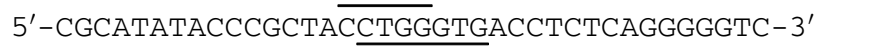 \\
\hline$\# 16$ & $3756-3762$ & $5^{\prime}$-ATATACCCGCTACCTGGGTGACCTCTCAGGGGGTC-3' \\
\hline
\end{tabular}

Underlined sequence: sequence targeted for deletion. ZNF pair 13 was the most active pair.

$\mathrm{ORF}$, open reading frame; ZFN, zinc finger nucleases.

PCR products were resolved on a $10 \%$ TRIS/Borate/EDTA polyacrylamide high-resolution electrophoresis gel. Sequence analysis was further applied to confirm the mutations. Real-time PCR primers and probe sequences for total tissue RNA were the following: forward, 5'-GGCCCACGCATATACCCGC-3'; reverse, 5'-AGCCAGGCCTTCCCCAGAG-3'; double-dye oligonucleotide probe, FAM-AATGTTGAGCAGGAAGGCGGTCT-BHQ1 (fluorescein amidite, black hole quencher 1).

All rats were genotyped after rat tissue (tail or ear) DNA extraction using the DNeasy Blood \& Tissue Kit (Qiagen, Manchester, UK) and the following PCR amplification primers: WT, 5'-GGGGTTTTGACAGCTGGGC-3' (forward) and $5^{\prime}$-CCCAGGTAGCGGGTATATGC-3' (reverse); mutant, $5^{\prime}$-GGTGGCCCACGCATACTGG- $3^{\prime}$ (forward) and 5'-GTCAGCATCCGAAGCCTGG-3' (reverse). After an initial denaturation step $\left(95^{\circ} \mathrm{C}\right.$ for 5 minutes $)$, samples were subjected to 30 cycles of denaturation at $95^{\circ} \mathrm{C}$ ( 1 minute), annealing $\left(60^{\circ} \mathrm{C}\right.$ for 1 minute), and extension $\left(72^{\circ} \mathrm{C}\right.$ for 1 minute). A final extension step $\left(72^{\circ} \mathrm{C}\right.$ for 1 minute) was performed.

Hmoxl knockout animals (homozygotes, Hmoxl ${ }^{-1-}$ ) were generated through breeding of the $\mathrm{HmoxI}^{+/-}$rats. Cross-breeding of the Hmoxl ${ }^{+/-}$rats did not yield the expected mendelian ratio. This finding is in agreement with those described earlier in mice lacking Hmoxl. ${ }^{12}$ Hmoxl $^{-1-}$ rats had growth retardation compared with their WT littermates, and most died at 6 months of age, without any previous signs of abnormality. They otherwise appeared healthy with respect to fur color and motility.

\section{Generation of $\mathrm{GEC}^{\mathrm{HO}-1}$ Rats by SB \\ Transposon-Mediated Transgenesis}

As previously described, ${ }^{13}$ GEC $^{\mathrm{HO}-1}$ rats were generated using a Sleeping Beauty (SB) transposon vector, SB human HO-1, harboring a FLAG-tagged human HO-1 sequence under the control of a murine nephrin promoter ${ }^{7}$ and the SB transposon system methodology, as reported by Katter et al. ${ }^{14}$ All rats were genotyped after rat tissue (tail or ear)
DNA extraction using the DNeasy Blood \& Tissue Kit (Qiagen) and the following PCR amplification primer pairs: SB1, 5'-GAGGGAAGAGAGAAGGGCGAGT-3' (forward) and $5^{\prime}$-CCTTGTTGCGCTCAATCTCCT-3' (reverse); SB2, $5^{\prime}$-CGACAGCATGCCCCAGGATT- $3^{\prime}$ (forward) and $5^{\prime}$-CTCTGGGAGTCTCCACGGGG-3' (reverse). After an initial denaturation step $\left(95^{\circ} \mathrm{C}\right.$ for 5 minutes), samples were subjected to 30 cycles of denaturation at $95^{\circ} \mathrm{C}$ ( 1 minute), annealing $\left(60^{\circ} \mathrm{C}\right.$ for 1 minute), and extension $\left(72^{\circ} \mathrm{C}\right.$ for 1 minute). A final extension step $\left(72^{\circ} \mathrm{C}\right.$ for 1 minute) was performed.

\section{Anti-GBM Rat Model of Glomerular Injury}

The model of anti-GBM antibody-mediated, complementdependent glomerulonephritis was induced as we previously reported. ${ }^{6}$ Briefly, rats were immunized with $500 \mu \mathrm{g}$ i.p. of rabbit $\operatorname{IgG}$ emulsified in complete Freund's adjuvant (Sigma-Aldrich) 1 week before a single subnephritogenic i.v. injection of $1 \mathrm{~mL}$ of rabbit anti-rat GBM serum. Control rats were preimmunized with rabbit IgG in complete Freund's adjuvant and subsequently injected with nonimmune rabbit serum. Urine was collected using metabolic cages 4 days before preimmunization with rabbit $\operatorname{IgG}$ and 7 days after the administration of the anti-GBM antibody. Urinary albumin was measured using an enzyme-linked immunosorbent assay method (Nephrat kit; Exocell, Philadelphia, PA). Urinary and serum creatinine concentrations were measured by the Jaffe colorimetric method. Albuminuria was expressed as the ratio of urinary albumin to urinary creatinine.

\section{Isolation and Treatment of Glomeruli}

Glomeruli were isolated from the kidneys of WT or transgenic animals by an established differential sieving method. ${ }^{15}$ Glomeruli were incubated with defined concentrations of the following metalloporphyrins (MPs): hemin, cobalt protoporphyrin, zinc protoporphyrin, tin protoporphyrin, SnMP, and PPIX. MPs were dissolved in dimethyl 
sulfoxide. Negative controls consisted of glomeruli incubated with MP vehicle (dimethyl sulfoxide) only. Protein extracts were prepared using lysis buffer $(150 \mathrm{mmol} / \mathrm{L}$ $\mathrm{NaCl}, 50 \mathrm{mmol} / \mathrm{L}$ Tris $\mathrm{pH} 8.0$, and $1 \%$ Triton X-100 containing a protease-inhibitors cocktail), and concentration was determined by the Bradford assay (BioRad Laboratories, Hercules, CA). Glomerular RNA was extracted using an established TRIzol-based method.

\section{Western Blot Analysis}

Protein lysates were resolved by SDS-PAGE, transferred onto polyvinyledinedifluoride membrane, and probed with primary antibodies overnight. Secondary antibodies were purchased from Cell Signaling Technology, and ECL reagent, from Santa Cruz Biotechnology (Dallas, TX). Equal loading was determined by probing for $\beta$-actin or glyceraldehyde-3-phosphate dehydrogenase.

\section{Real-Time and RT-PCR Amplification}

RT-PCR reactions were performed using a TaqMan Reverse Transcription Reagents kit (Applied Biosystems, Waltham, MA). Reactions were performed in a PTC-200 PCR cycler (MJ Research, Bio-Rad Laboratories, Hercules, CA) with a Chromo4 detector system (Bio-Rad) under the following conditions: $25^{\circ} \mathrm{C}$ for 10 minutes, $48^{\circ} \mathrm{C}$ for 30 minutes, and $95^{\circ} \mathrm{C}$ for 5 minutes. Each reaction consisted of $2 \mu \mathrm{L}$ of primer-probe assay mix (Integrated DNA Technologies, Coralville, IA), $10 \mu \mathrm{L}$ of Master Mix (Applied Biosystems), and $8 \mu \mathrm{L}$ of cDNA. Reactions were performed in triplicate, and results were analyzed by the $\Delta \Delta \mathrm{CT}$ method.

\section{Histologic Examination and Immunostaining}

Kidney cortical sections obtained after nephrectomy were fixed in formalin $30 \%$. Sections were stained with periodic acid-Schiff following established methodology. Glomerular damage was quantified as previously described by assessing glomerular size and cellularity. ${ }^{4}$ Immunofluorescence for $\mathrm{C} 3 \mathrm{~b}$ deposition or rabbit $\mathrm{IgG}$ deposition in glomeruli was performed on cryosections using a mouse anti-rat $\mathrm{C} 3 / \mathrm{C} 3 \mathrm{~b}$ primary antibody and a goat anti-mouse secondary antibody labeled with Alexa Fluor 568 or a goat anti-rabbit secondary labeled with Alexa Fluor 488, respectively (Thermo Fisher Scientific, Renfrew, UK). Sections incubated in the absence of primary antibody (secondary antibody only) served as negative controls. In immunohistochemistry detection of DAF in kidney cortical sections, an anti-DAF antibody (clone RDIII-7) and standard techniques were used.

\section{Statistical Analysis}

Values are expressed either as means \pm SEM or as means \pm SD. Statistical analysis was performed with either $t$-test, where applicable, or analysis of variance for more than two group comparisons. When significant, post hoc analysis was performed, with either a Turkey test or the least significant difference test. A $P$ value $<0.05$ was chosen as statistically significant.

\section{Results}

\section{Characterization of Glomerular DAF}

Binding specificity of the anti-DAF antibody used was verified by immunohistochemistry analysis. Figure 1A demonstrates antibody binding exclusively in glomeruli and GECs, confirming the findings from a previous report of restricted DAF expression to GECs in the rat nephron. ${ }^{9}$ To confirm that DAF protein is preserved in its glycosylated, glycosylphosphatidylinositol (gpi)-anchored form, after glomerular isolation, glomeruli were treated with phosphatidylinositolspecific phospholipase $\mathrm{C}$ at various concentrations for 90 minutes at $37^{\circ} \mathrm{C}$. Phosphatidylinositol-specific phospholipase $\mathrm{C}$ treatment resulted in a loss of DAF protein of approximately $90 \%$ (Figure 1B). To assess the glycosylation state of gpi-anchored DAF, glomerular protein lysates were subjected to enzymatic deglycosylation using deglycosylation enzymes alone or in combination. The presence of a heavily glycosylated DAF protein was demonstrated. Neuraminidase treatment resulted in a band of approximately $52 \mathrm{kDa}$ (Figure 1C). Treatment with $O$-glycosidase combined with either neuraminidase or $\mathrm{N}$-glycosidase $\mathrm{F}$ further reduced DAF molecular weight to approximately $47 \mathrm{kDa}$ (Figure $1 \mathrm{~B}$ ). The addition of two more enzymes [ $\beta-(1-4)$-galactosidase and $\beta$ - $N$-acetylglucosaminidase] to the previous enzyme mix resulted in a band of approximately $43 \mathrm{kDa}$ (Figure 1C), representing the fully deglycosylated, gpi-anchored glomerular DAF protein.

\section{H0-1 Regulates Constitutive DAF Expression}

The regulatory effect of $\mathrm{HO}-1$ on glomerular DAF was initially assessed in the Hmox-1-deficient rats. As shown in Figure 2A, Hmox-1 protein in the glomeruli isolated from the moxl $^{-1-}$ rats was completely absent, whereas in the glomeruli of the Hmoxl ${ }^{+/-}$animals, there was a significant reduction in Hmox-1 protein compared with that in the WT animals. Constitutive DAF expression was significantly reduced at both the mRNA and protein levels in the glomeruli of both the Hmoxl $^{-1-}$ rats (Figure 2, B and C) and the $\mathrm{Hmoxl}^{+/-}$rats (Figure 2, A and B). A significant increase in constitutive DAF expression was observed in the glomeruli isolated from the $\mathrm{GEC}^{\mathrm{HO}-1}$ rats compared to those from the WT rats, supporting the regulation of DAF by HO-1 (Figure 2D).

\section{GEC-Targeted H0-1 Overexpression Reduces Complement Deposition and Proteinuria in Anti-GBM Antibody-Mediated Injury}

We next examined whether complement deposition and extent of injury (proteinuria) in the $\mathrm{GEC}^{\mathrm{HO}-1}$ rats are 


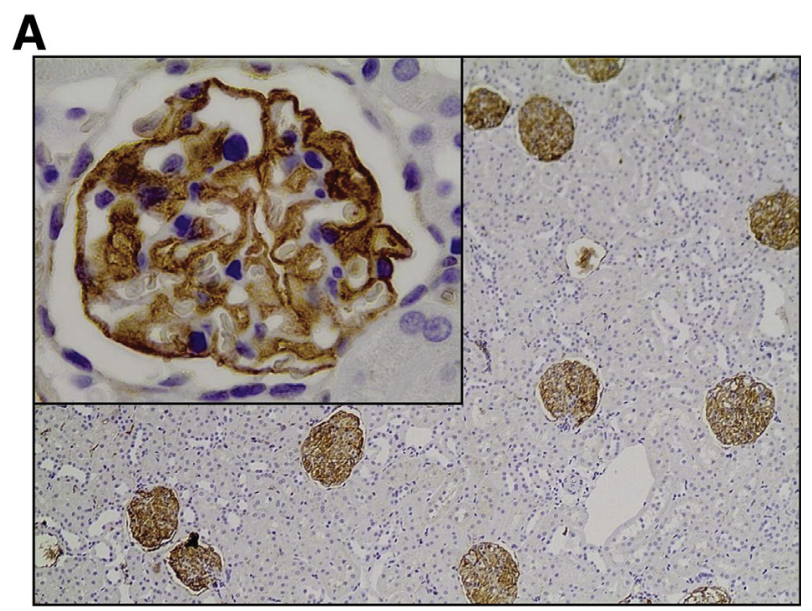

B

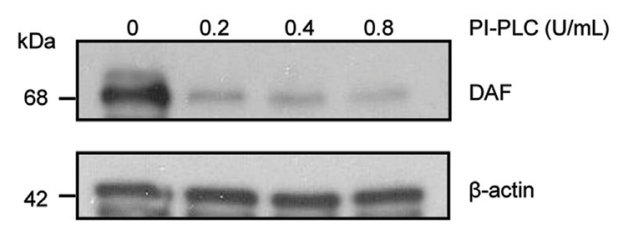

C

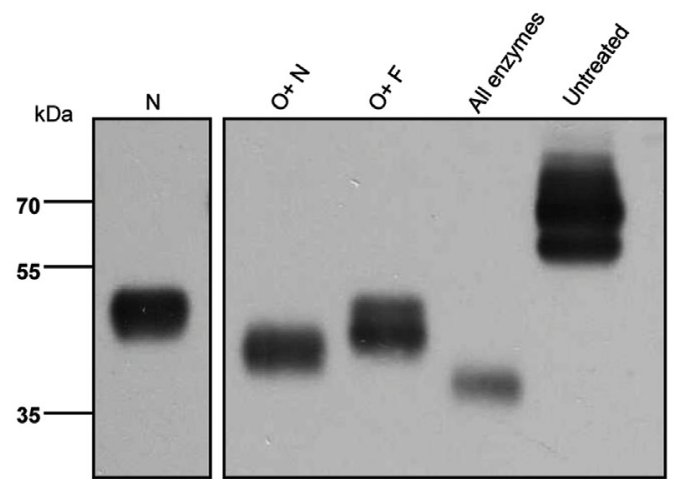

Figure 1 Characterization of glomerular decay accelerating factor (DAF) protein. A: Immunohistochemical localization of DAF in kidney cortical sections using anti-DAF antibody (clone RDIII-7). The inset shows glomerular epithelial cells. B: Wild-type (WT) glomeruli were isolated and incubated with increasing concentrations of phosphatidylinositol-specific phospholipase C (PI-PLC) for 90 minutes to confirm the presence of glycosylphosphatidylinositol-anchored DAF protein in glomeruli. Total protein lysates were analyzed by Western blot analysis for DAF protein. $\beta$-Actin was used as a loading control. C: WT glomerular protein extracts were incubated with the deglycosylation enzyme [neuraminidase $(\mathrm{N})$ ], alone or in combination with 0 -glycosidase $(0)$ or $N$-glycosidase $F(F)$. Incubations with all deglycosylation enzymes available [addition of $\beta-(1-4)$-galactosidase, and $\beta-N$-acetylglucosaminidase to a mixture of the three previous enzymes] were also performed. Protein samples were analyzed by Western blot analysis. Original magnification: $\times 10(\mathbf{A}$, main image); $\times 400$ (A, inset).

reduced in a model of anti-GBM antibody-mediated, complement-dependent glomerular injury. At the time point chosen for the studies performed (day 7), proteinuria was associated with minimal inflammatory cell infiltration in the glomeruli, segmental areas of glomerular hypercellularity, and no crescent formation or scaring (Figure 3). Quantification of injury by the assessment of changes in glomerular size and cellularity (nuclear count) revealed no differences in glomerular size between any two groups of animals, and a statistically significant increase in nuclear count in the glomeruli of the WT rats treated with anti-GBM compared with those in all of the other groups (Table 2). In the $\mathrm{GEC}^{\mathrm{HO}-1}$ rats treated with anti-GBM antibody, albuminuria (ratio of urinary albumin to urinary creatinine) was no different from that in the $\mathrm{GEC}^{\mathrm{HO}-1}$ or WT controls treated with nonimmune rabbit serum (Figure 4A), but was significantly increased compared with that in the antiGBM-treated WT rats. No differences in serum creatinine values were observed between any two groups of animals (Table 3). As shown in Figure 4B, a marked reduction in glomerular $\mathrm{C} 3 \mathrm{~b}$ deposition was observed in the glomeruli of the $\mathrm{GEC}^{\mathrm{HO}-1}$ rats treated with anti-GBM antibody compared with that in the antibody-treated WT controls. This observation was corroborated by immunofluorescence staining for $\mathrm{C} 3 \mathrm{~b}$ deposition (Figure 4C). Staining for rabbit IgG ruled out differences in the extent of anti-GBM antibody deposition in the GBM (Figure 4C).

\section{Effect of Hemin-Mediated H0-1 Induction on Glomerular DAF Expression}

The observation that Hmox-1 overexpression up-regulated DAF raised the question of whether DAF up-regulation also occurs in response to Hmox-1 induction. We initially examined the effect of the natural Hmox substrate/inducer, hemin. The hemin concentrations chosen (50 to $400 \mu \mathrm{mol} /$ L) reflect those likely attained within the glomerular milieu in hematuric forms of glomerular injury owing to release of heme from circulating red blood cells undergoing membrane damage while passing through injured glomeruli. ${ }^{16}$

Hemin (50 to $400 \mu \mathrm{mol} / \mathrm{L}$ ) increased glomerular DAF protein levels in a concentration-dependent manner (Figure 5A). A statistically significant increase in DAF protein was observed at concentrations of 200 and $400 \mu \mathrm{mol} / \mathrm{L}$ (Figure 5A). The time-dependent effect of hemin on DAF at these concentrations is shown in Figure 5B. Treatment with 200 or $400 \mu \mathrm{mol} / \mathrm{L}$ hemin increased DAF protein by as early as 2 hours. DAF mRNA levels were also significantly increased at the same hemin concentrations (Figure 5C).

To determine the extent to which HO-1 modulates the increase in DAF expression in response to hemin, we assessed DAF levels in the glomeruli isolated from the Hmoxl $^{-1-}$ and GEC ${ }^{\mathrm{HO}-1}$ animals. As shown in Figure 6A, baseline DAF protein levels were lower in the Hmox1 ${ }^{-1-}$ glomeruli, and the increase in DAF protein in response to hemin was attenuated compared to that in the WT glomeruli(Figure 6A). In the glomeruli from the $\mathrm{GEC}^{\mathrm{HO}-1}$ rats, baseline DAF expression was increased compared with that in the WT rats, while DAF induction in response to hemin was augmented (Figure 6B).

To examine the extent to which hemin-mediated DAF induction is dependent on de novo protein synthesis, glomeruli were preincubated with the protein-synthesis 

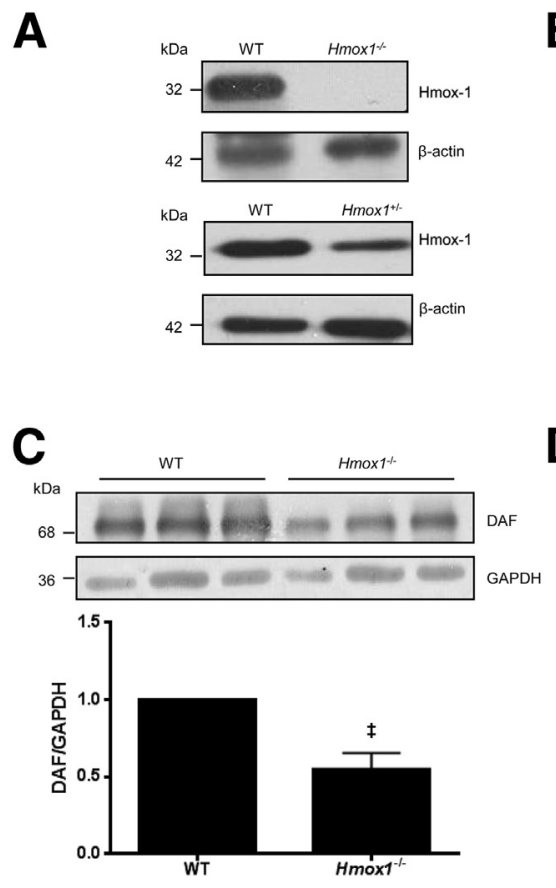

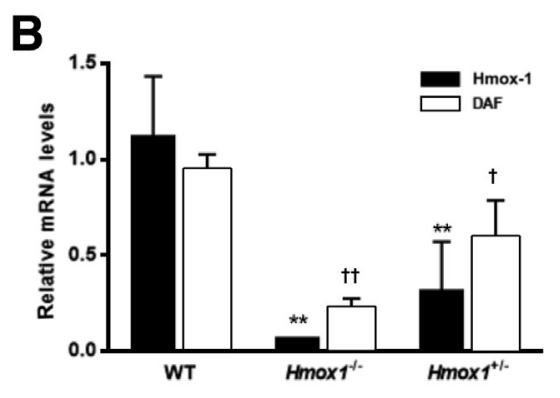

D
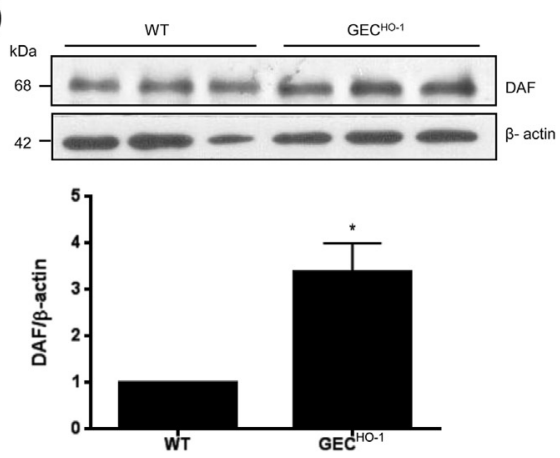

Figure 2 Heme oxygenase (Hmox)-1 regulates glomerular decay accelerating factor (DAF) expression. Glomeruli were isolated from wild-type (WT), $H \operatorname{mox} 1^{+/-}$, or $\mathrm{Hmox}^{-/-}$rats, or rats with glomerular epithelial cell-targeted $\mathrm{H} 0-1$ overexpression $\left(\mathrm{GEC}^{\mathrm{HO}-1}\right)$. A: Total protein lysates from WT, $\mathrm{Hmox}^{+/-}$, and $\mathrm{Hmox}^{-/-}$glomeruli were analyzed by Western blot analysis for Hmox-1 protein. B: mRNA levels were analyzed by real-time PCR amplification. C: Total protein lysates from WT and $\mathrm{Hmox}^{-1-}$ glomeruli were analyzed by Western blot analysis for DAF protein. D: DAF expression in WT and $\mathrm{GEC}^{\mathrm{HO}-1}$ glomeruli. Data are expressed as means \pm SEM. $n=3$ per group. ${ }^{\star} P<0.05$ (unpaired $t$-test), ${ }^{* *} P<0.01$ versus Hmox-1 mRNA levels in WT (analysis of variance and post hoc analysis by the least significant difference test); ${ }^{\dagger} P<0.05$, ${ }^{\dagger} P<0.01$ versus DAF mRNA levels in WT (analysis of variance and post hoc analysis by the least significant difference test); ${ }^{\ddagger} P<0.05$ versus WT (unpaired $t$-test). GAPDH, glyceraldehyde-3-phosphate dehydrogenase. inhibitor CHX (10 mg/mL) and subsequently incubated with hemin $(200$ or $400 \mu \mathrm{mol} / \mathrm{L})$. Levels of DAF and Hmox-1 expression were assessed at the mRNA and protein levels. In the glomeruli not preincubated with $\mathrm{CHX}$, hemin increased gpi-DAF (Figure 7A), as well as DAF precursor protein and Hmox-1 (Figure 7A). Pretreatment with $\mathrm{CHX}$ abolished the increase in DAF mRNA in hemin-treated glomeruli (Figure 7B) as well as the levels of expression of DAF precursor protein and Hmox-1 (Figure 7A), but it had no effect on the increase in gpi-DAF protein (Figure 7A).
Collectively, these observations indicate that HO-1 regulates constitutive DAF expression and hemin-mediated DAF induction. Hemin may also increase DAF at a posttranslational level in the absence of HO-1.

\section{Effect of Noniron Hemin Analogues on Glomerular DAF Expression}

We next assessed the effect of hemin structural analogues varying in metal or porphyrin functionalities on the ability to increase or inhibit $\mathrm{HO}$ activity. Of the noniron hemin
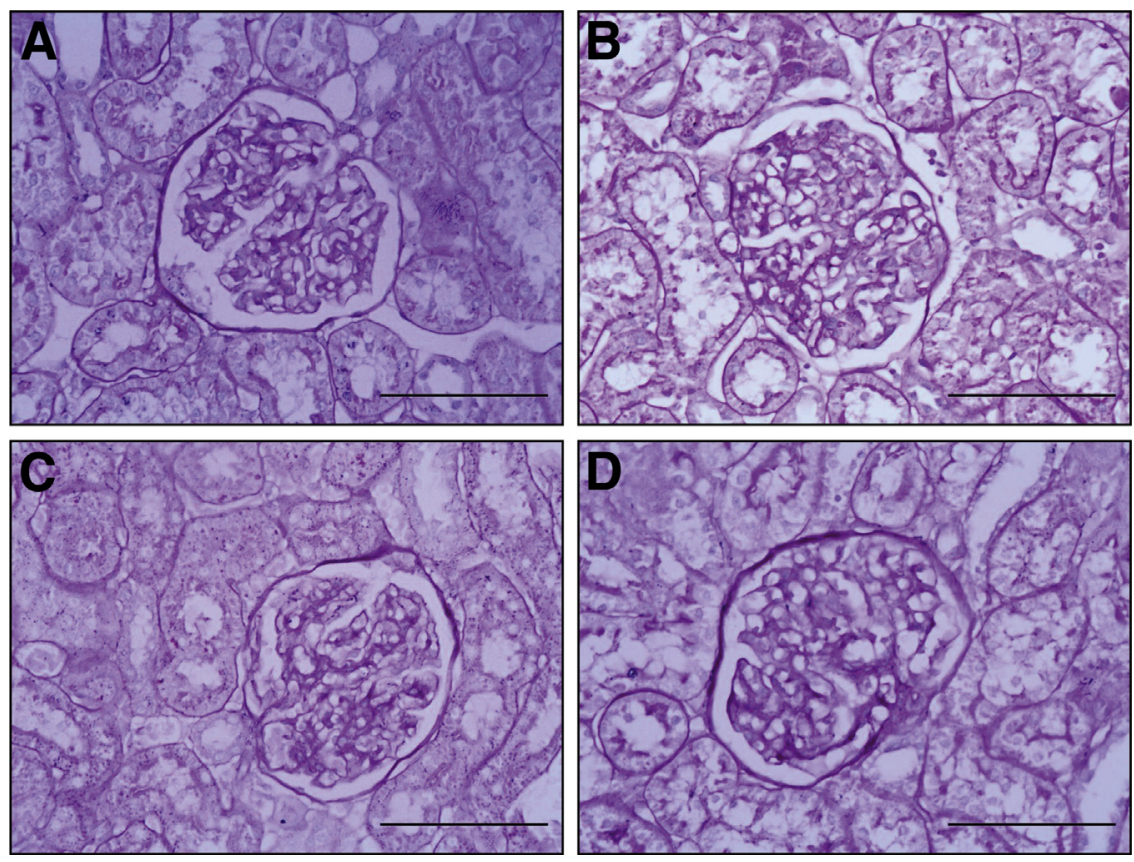

Figure 3 Attenuation of glomerular lesions in rats with glomerular epithelial cell-targeted heme oxygenase 1 overexpression $\left(\mathrm{GEC}^{\mathrm{HO}-1}\right)$. Histologic examination of glomeruli from a wild-type (WT) rat treated with nonimmune rabbit serum $(\mathbf{A})$, a WT rat treated with anti-glomerular basement membrane (GBM) antibody (B), a $\mathrm{GEC}^{\mathrm{HO}-1}$ rat treated with nonimmune rabbit serum (C), and a $\mathrm{GEC}^{\mathrm{HO}-1}$ rat treated with anti-GBM antibody (D). Sections were stained with periodic acid Schiff stain. Segmental areas of hypercellularity without scaring or crescent formation in B but not in $\mathbf{D}$. Scale bars $=50 \mu \mathrm{m}$. Original magnification, $\times 400$. 
Table 2 Quantification of Glomerular Damage in WT and GEC ${ }^{\mathrm{HO}-1}$ Animals Treated with Nonimmune Rabbit Serum (Control) or Anti-GBM Antibody

\begin{tabular}{|c|c|c|c|c|}
\hline Glomerular characteristics & WT control & WT anti-GBM & $\mathrm{GEC}^{\mathrm{HO}-1}$ control & $\mathrm{GEC}^{\mathrm{HO}-1}$ anti-GBM \\
\hline Glomerular area, $\mu \mathrm{m}^{2}$ & $9944 \pm 1265$ & $11,410 \pm 1493$ & $9509 \pm 790.3$ & $9746 \pm 607.8$ \\
\hline Nuclear count & $42.32 \pm 4.011$ & $80.82 \pm 9.744^{* * *, \dagger \dagger}$ & $48.02 \pm 2.26$ & $54.62 \pm 4.466$ \\
\hline
\end{tabular}

Data are expressed as means \pm SD. $n=4$. Statistical analyses were performed by analysis of variance and post hoc analysis by a Turkey test.

$* * * P<0.001$ versus WT control; ${ }^{\dagger \dagger} P<0.01$ versus $\mathrm{GEC}^{\mathrm{HO}-1}$ treated with anti-GBM.

$\mathrm{GBM}$, glomerular basement membrane; $\mathrm{GEC}^{\mathrm{HO}-1}$, heme oxygenase 1 overexpression targeted to glomerular epithelial cells; WT, wild-type.

analogues, cobalt protoporphyrin is an established HO-1 inducer and was used at concentrations the same as those of hemin. A dose-dependent DAF induction similar to that in response to hemin was observed (Figure 8A). Tin protoporphyrin, zinc protoporphyrin, and SnMP are established competitive $\mathrm{HO}$ enzyme-activity inhibitors and were used at concentrations that inhibit Hmox activity in vitro. ${ }^{17-21}$ All three MPs dose-dependently increased glomerular DAF protein (Figure 8, B-D), indicating that this increase occurs independently of metal moiety, porphyrin structure, or $\mathrm{HO}$ activity.

To further confirm that DAF up-regulation occurs independently of metal moiety, the effect of the metal-devoid PPIX was assessed. A dose-dependent increase in DAF protein was observed (Figure 8E), suggesting that the porphyrin (tetrapyrrole) ring alone is a DAF inducer.

\section{DAF Induction by SnMP or PPIX Reduces $C 3 b$ in Glomeruli}

The observation that noniron MPs increased glomerular DAF expression prompted us to examine whether this increase is sufficient to limit $\mathrm{C} 3 \mathrm{~b}$ deposition. This theory was determined in isolated glomeruli incubated with normal rat serum (NRS), as a source of complement, to induce spontaneous complement activation.

Glomeruli were initially incubated for 18 hours in the presence of heat-inactivated rat serum or various dilutions of NRS alone. As shown in Figure 9A, C3b protein was undetectable in the glomeruli incubated with heat-inactivated NRS. Moreover, there was a progressive increase in $\mathrm{C} 3 \mathrm{~b}$ protein inversely proportional to NRS dilutions (Figure 9A).

To determine whether DAF induction by MPs specifically reduces $\mathrm{C} 3 \mathrm{~b}$ formation, WT glomeruli were incubated for 18 hours with media containing $10 \%$ NRS in the presence of increasing concentrations of SnMP (50 to $100 \mu \mathrm{mol} / \mathrm{L}$ ). As shown in Figure 9B, C3b protein was reduced to nearcontrol levels. A similar reduction in $\mathrm{C} 3 \mathrm{~b}$ was observed in the glomeruli incubated with PPIX (50 to $100 \mu \mathrm{mol} / \mathrm{L}$ ) (Figure 9C). Treatment with a DAF-blocking antibody (RDIII-7) alone significantly increased C3b protein in the glomeruli incubated with NRS. This increase was reversed in the presence of PPIX $(50 \mu \mathrm{mol} / \mathrm{L})$. Similar results were obtained with SnMP (not shown).

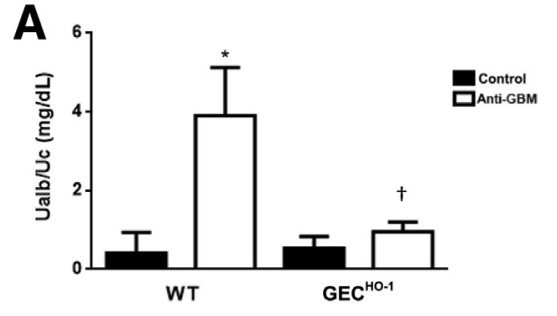

B

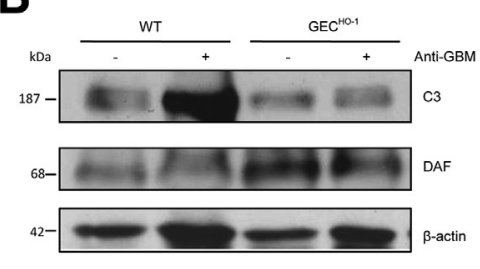

C

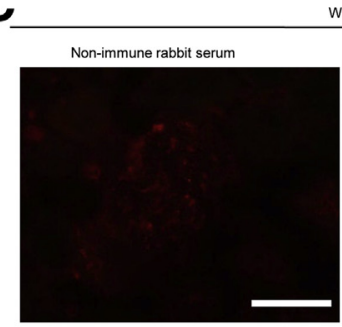

wT
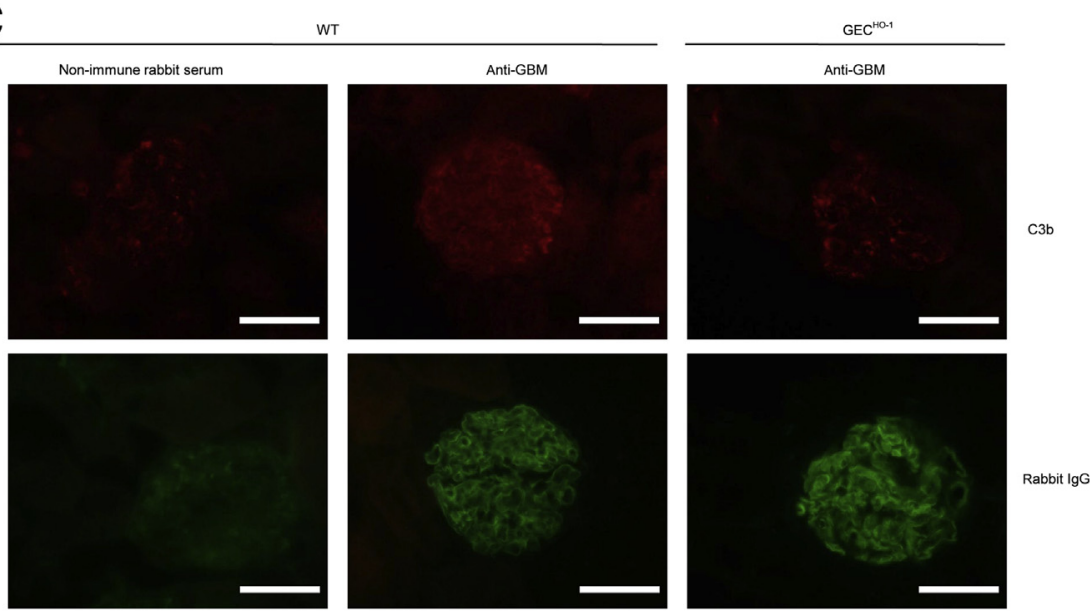

Figure 4 Heme oxygenase (H0)-1 overexpression reduces complement component C3 fragment $b(\mathrm{C} 3 \mathrm{~b})$ deposition and proteinuria after anti-glomerular basement membrane (GBM) treatment. Glomeruli were isolated from wild-type (WT) rats, rats with glomerular epithelial cell-targeted heme oxygenase 1 overexpression $\left(\mathrm{GEC}^{\mathrm{HO}-1}\right)$ treated with anti-GBM, or WT and GEC ${ }^{\mathrm{HO}-1}$ controls that were treated with nonimmune rabbit serum. A: Urinary albumin $\left(U_{\text {alb }}\right)$ excretion factored by urinary creatinine excretion (Uc) in WT or GEC $\mathrm{CH}^{\mathrm{HO}-1}$ rats treated with nonimmune rabbit serum (controls) and in WT or $\mathrm{GEC}^{\mathrm{HO}-1}$ rats treated with anti-GBM antibody. B: Total glomerular protein lysates were analyzed by Western blot analysis for C3b and decay accelerating factor (DAF) protein levels. Representative Western blot from three independent experiments. C: Immunofluorescence staining for $\mathrm{C} 3 \mathrm{~b}$ or rabbit $\mathrm{IgG}$ in glomeruli of WT rats treated with nonimmune rabbit serum or anti-GBM antibody and glomeruli of $\mathrm{GEC}^{\mathrm{HO}-1}$ rats treated with anti-GBM antibody. Data are expressed as means \pm SEM. $n=4$ per group. ${ }^{\star} P<0.05$ versus WT control; ${ }^{\dagger} P<0.05$ versus WT treated with anti-GBM antibody. Scale bars $=50 \mu \mathrm{m}$ (C). 
Table 3 Serum Creatinine Values in WT or GEC ${ }^{\mathrm{HO}-1}$ Rats Treated with Nonimmune Rabbit Serum (Control) or Anti-GBM Serum

\begin{tabular}{lllll}
\hline & WT control & WT anti-GBM & GEC $^{\text {HO-1 }}$ control $^{\text {GEC }}$ & anti-GBM \\
\hline Serum creatinine, $\mathrm{mg} / \mathrm{dL}$ & $0.4167 \pm 0.1804$ & $0.5556 \pm 0.2406$ & $0.3125 \pm 0.225$ & $0.3125 \pm 0.4253$ \\
\hline
\end{tabular}

Data are expressed as means \pm SD. $n=4$.

GBM, glomerular basement membrane; GEC $\mathrm{CH}^{\mathrm{HO}-1}$, heme oxygenase 1 overexpression targeted to glomerular epithelial cells; WT, wild-type.

\section{Discussion}

The mechanism by which HO-1 mediates cytoprotective effects has been controversial. Since heme degradation is the only well-established reaction catalyzed by $\mathrm{HO}$ and the only mechanism by which cells can generate carbon monoxide, it is widely accepted that heme-degradation products (ie, carbon monoxide and biliverdin) mediate the cytoprotective effects of HO-1 induction.

However, the source of HO-1 substrate (intracellular free heme) has been a concern since $>95 \%$ of heme in the body is bound to hemoglobin and myoglobin within red blood cells and muscle tissue, respectively. In other tissues, cellular free heme was estimated to be present at very low concentrations not exceeding $30 \mathrm{nmol} / \mathrm{L} .^{22}$ Thus, apart from hemolytic conditions, in which plasma heme concentrations can approach $200 \mu \mathrm{mol} / \mathrm{L},{ }^{23}$ there may be a limited amount of heme available for catabolism by $\mathrm{HO}$ into cytoprotective heme-degradation products. The observation that the overexpression of mutated $\mathrm{HO}$ incapable of catalyzing heme degradation is still able to protect against oxidative stress ${ }^{24}$ further emphasizes that $\mathrm{HO}-1-$ mediated cytoprotection may occur independently of heme-degradation products.

The present study establishes $\mathrm{HO}-1$ as a regulator of glomerular DAF and points to HO-1-mediated DAF upregulation as an alternative mechanism by which HO-1 confers protection against complement-mediated injury. This mechanism was examined using transgenic rats with Hmox-1 deficiency or GEC-targeted HO-1 overexpression and in vivo and in vitro models of complement activation.

In the model of anti-GBM antibody-mediated, complement-dependent injury induced in the rats with $\mathrm{GEC}^{\mathrm{HO}-1}$, there was reduced $\mathrm{C} 3 \mathrm{~b}$ deposition in glomeruli and attenuation of proteinuria. In this model, we previously reported that glomerular Hmox-1 induction by the administration of exogenous heme (hemin) or $\mathrm{GEC}^{\mathrm{HO}-1}$ in mice

\section{A}
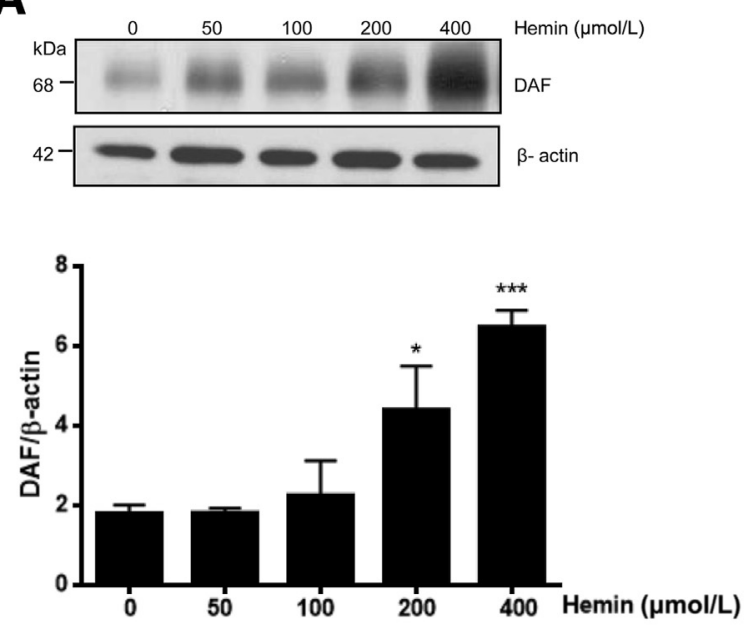

C

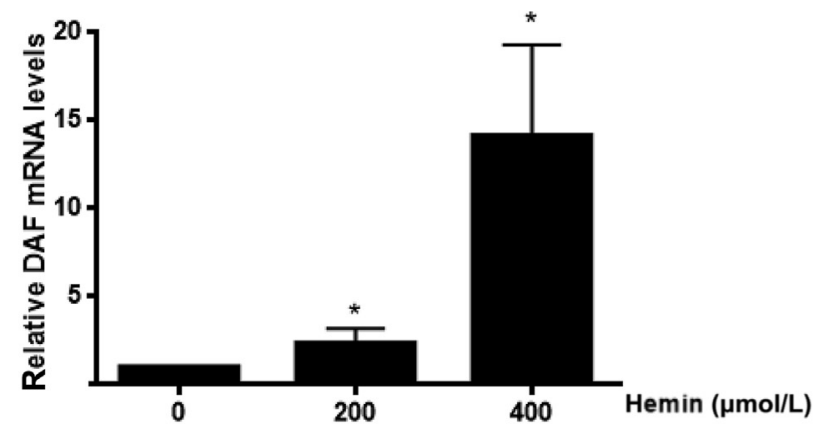

B
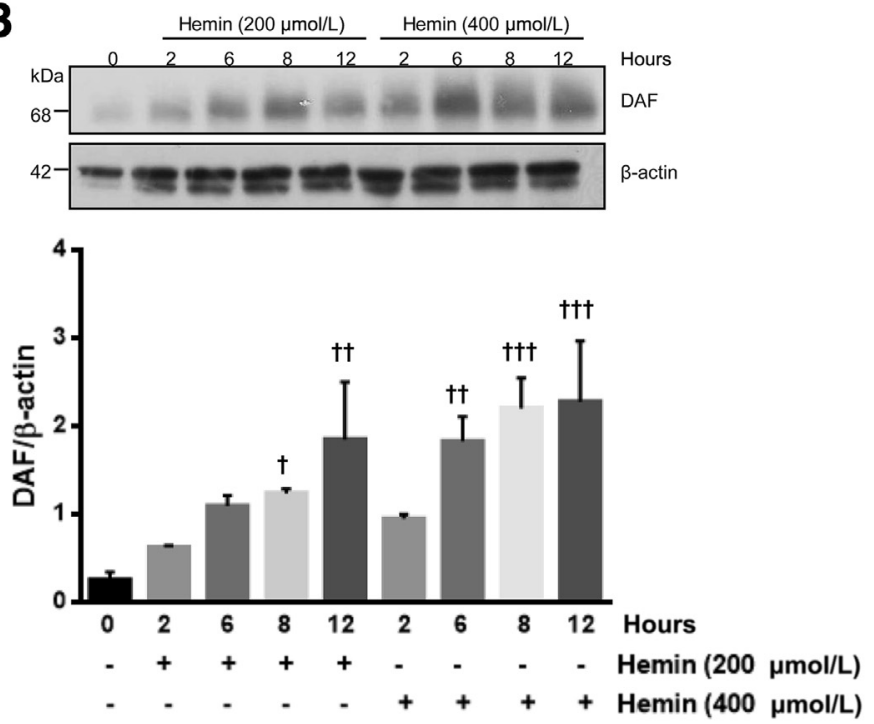

Figure 5 Concentration- and time-dependent effects of hemin on glomerular decay accelerating factor (DAF) expression. Glomeruli were isolated and treated with increasing concentrations of hemin (50 to $400 \mu \mathrm{mol} / \mathrm{L}$ ) for 18 hours. A: Total protein lysates were analyzed by Western blot analysis for DAF expression. Representative Western blots from three independent experiments are shown. B: Glomeruli were treated with hemin (200 or $400 \mu \mathrm{mol} / \mathrm{L}$ ) at various time points, and total protein lysates were analyzed by Western blot analysis for DAF protein. Representative Western blots are shown. $\beta$-Actin was used as a loading control. C: DAF mRNA levels were determined by real-time PCR amplification. Data are expressed as means \pm SEM. $n=3$ independent experiments $(\mathbf{A}$ and $\mathbf{B})$; $n=3$ per group $(\mathbf{C}) .{ }^{*} P<0.05,{ }^{*} * * P<0.001$ versus 0 hemin; ${ }^{\dagger} P<0.05$, ${ }^{\dagger \dagger} P<0.01$, and ${ }^{\dagger \dagger \dagger} P<0.001$ versus 0 hour (analysis of variance and post hoc analysis by the least significant difference test). 

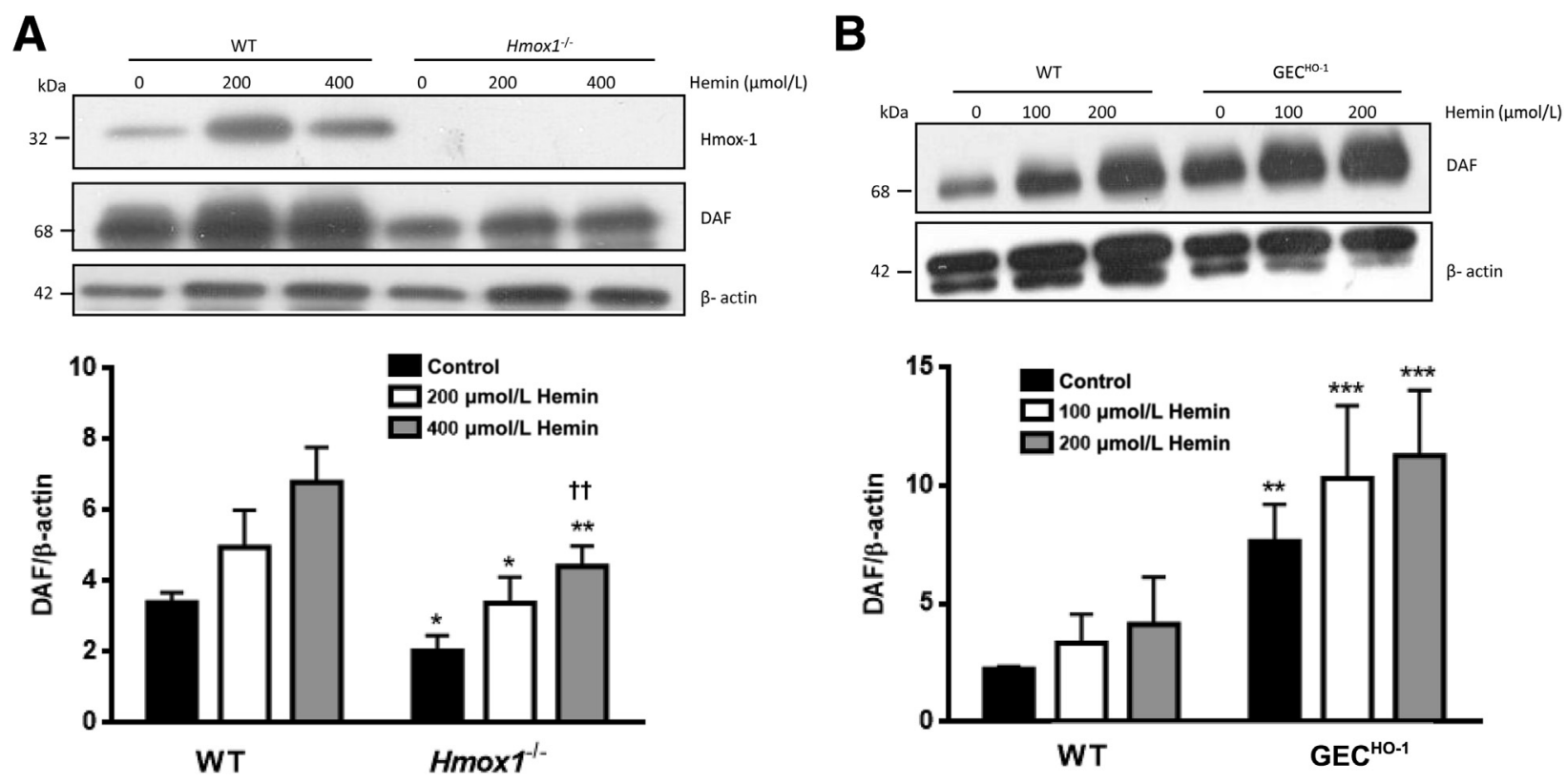

Figure 6 Role of heme oxygenase (Hmox)-1 in hemin-mediated decay accelerating factor (DAF) induction. A: Glomeruli were isolated from Hmox $1^{-/-}$and wild-type (WT) rats treated with increasing concentrations of hemin $(200,400 \mu \mathrm{mol} / \mathrm{L})$ for 18 hours, and total protein lysates were analyzed by Western blot analysis for Hmox-1 and DAF protein expression. Representative Western blot from three independent experiments are shown. B: glomerular epithelial cell-targeted Hmox-1 overexpression (GEC ${ }^{\mathrm{HO}-1}$ ) or WT glomeruli were treated with increasing concentrations of hemin $(100,200 \mu \mathrm{mol} / \mathrm{L})$ for 18 hours. Total protein lysates were analyzed by Western blot analysis for DAF protein. Representative Western blot is shown. $\beta$-Actin was used as a loading control. Data are expressed as means \pm SEM densitometry values. $n=3$ independent experiments. ${ }^{*} P<0.05,{ }^{*} P<0.01$, and ${ }^{*} * * P<0.001$ versus corresponding WT; ${ }^{\dagger \dagger} P<0.01$ versus control $H_{m o x} 1^{-/-}$(analysis of variance and post hoc analysis by the least significant difference test).

reduces proteinuria. ${ }^{6,7}$ The present study points to upregulation of glomerular DAF by HO-1 as a possible underlying mechanism. Definitive evidence for such a mechanism would require specific DAF blockade in vivo, for example via the administration of a DAF-neutralizing antibody, to demonstrate that such blockade reverses the reduction of proteinuria in animals with Hmox-1 overexpression in glomeruli. However, this approach has been previously shown to be of limited efficacy in inhibiting glomerular DAF due to binding of the systemically administered neutralizing antibody to diverse targets in blood cells and endothelia and because of the high molecular weight of the antibody, which limits the crossing of the glomerular barrier and binding to the GEC apical surface where DAF is located. ${ }^{\text {? }}$

We, therefore, used a DAF-neutralizing antibody to demonstrate that DAF induction specifically minimizes glomerular C3b deposition after spontaneous complement activation in isolated glomeruli incubated with NRS in vitro. In these experiments, we chose to use whole glomeruli instead of cultured GECs because, in contrast to cultured GECs, in which dedifferentiation occurs, ${ }^{25}$ whole glomeruli retain their unique tricellular structure, including the preservation of GEC structural integrity ex vivo. ${ }^{26}$ Moreover, DAF is exclusively expressed in GECs, in which it is preserved as glycosylated, gpi-anchored protein (Figure 1). In the in vitro spontaneous complement-activation model used, $\mathrm{C} 3 \mathrm{~b}$ generation occurs as a result of $\mathrm{C} 3$ hydrolysis in
NRS, a process known as tick-over, while the presence of complement receptor type 1 in rat $\mathrm{GECs}^{27}$ ensures $\mathrm{C} 3 \mathrm{~b}$ deposition. DAF induction by specific MPs resulted in reduced $\mathrm{C} 3 \mathrm{~b}$ deposition, and this effect was reversed by a DAF-neutralizing antibody (Figure 9D). The complete reversal of reduction in $\mathrm{C} 3 \mathrm{~b}$ deposition by the DAFneutralizing antibody used renders the contribution of other complement controllers, complement receptor 1 -related protein $\mathrm{Y}$ and CD59, also expressed in the rat glomerulus, unlikely.

It has previously been reported that the regulation of DAF expression by HO-1 involves heme-degradation products, specifically bilirubin, which was shown to induce DAF in human endothelial cells. ${ }^{8}$ However, the noniron hemin analogues (cobalt protoporphyrin, zinc protoporphyrin, tin protoporphyrin, and SnMP) used in our study cannot be metabolized to bile pigments or carbon monoxide and act as competitive Hmox-substrate inhibitors when used in vitro. ${ }^{28}$ Therefore, a similar effect on heme availability, specifically an increase in free heme levels, is expected from all. These MPs also induced glomerular DAF at concentrations lower than that of hemin (Figure 8). It is, therefore, unlikely that heme-degradation products play a mechanistic role in upregulating glomerular DAF.

A possible mechanism by which $\mathrm{HO}-1$ regulates DAF expression could involve the modulation of intracellular free heme levels. HO-1 overexpression may upregulate DAF indirectly by reducing cellular free heme content, as 

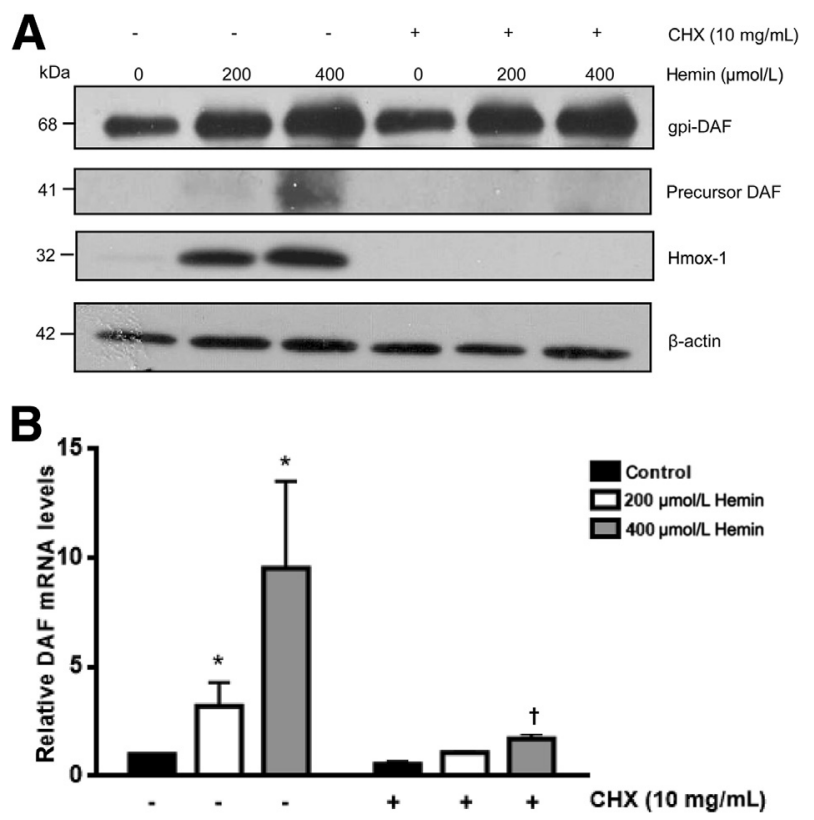

Figure 7 Effect of cycloheximide (CHX) on hemin-mediated decay accelerating factor (DAF) induction. Glomeruli were treated with CHX (10 $\mathrm{mg} / \mathrm{mL}$ ) for 4 hours, washed, and subsequently treated with increasing concentrations of hemin (200 to $400 \mu \mathrm{mol} / \mathrm{L}$ ) for 18 hours. A: Total protein lysates were analyzed by Western blot analysis for DAF or heme oxygenase (Hmox)-1 protein expression. $\beta$-Actin was used as loading control. Representative Western blot from three independent experiments. B: DAF mRNA levels were determined by real-time PCR amplification. Data are expressed as means \pm SEM. $n=3$ independent experiments. ${ }^{*} P<0.05$ versus control without $\mathrm{CHX} ;{ }^{\dagger} P<0.05$ versus control with $\mathrm{CHX}$ (analysis of variance and post hoc analysis by the least significant difference test).

previously shown, ${ }^{29}$ thus reducing the activity levels of heme-containing enzymes that catalyze the production of negative regulators of DAF expression. One such enzyme is nitric oxide (NO) synthase, which acts on L-arginine to generate NO. In rat glomeruli, there is a negative crosstalk between Hmox-1 and NO synthase, whereby increased Hmox-1 expression reduces inducible NO synthase enzyme activity. ${ }^{30}$ The decrease in NO production could upregulate DAF since NO was shown to be a negative regulator of DAF by the inhibition of binding of specificity protein 1 transcription factor to a specificity protein 1 site located within an NO-response element present in the core DAFpromoter region. ${ }^{31}$ Free heme was also shown to reduce prostaglandin $\mathrm{E}_{2}$ production, ${ }^{32}$ while prostaglandin $\mathrm{E}_{2}$ was demonstrated to upregulate DAF. ${ }^{33}$ By reducing free heme levels, $\mathrm{HO}-1$ overexpression may preserve prostaglandin $\mathrm{E}_{2}$ production, thus enhancing DAF expression. Hemin induced DAF in glomeruli lacking Hmox-1 (Figure 6A), and this finding was also observed under conditions of protein-synthesis inhibition by CHX (Figure 7A). These observations suggest the presence of a post-translational modification mechanism by which hemin can increase DAF. DAF is initially synthesized as a precursor protein of a low molecular weight (approximately $41 \mathrm{kDa}$ ) onto which the gpi anchor is attached. The gpi-anchored complex then
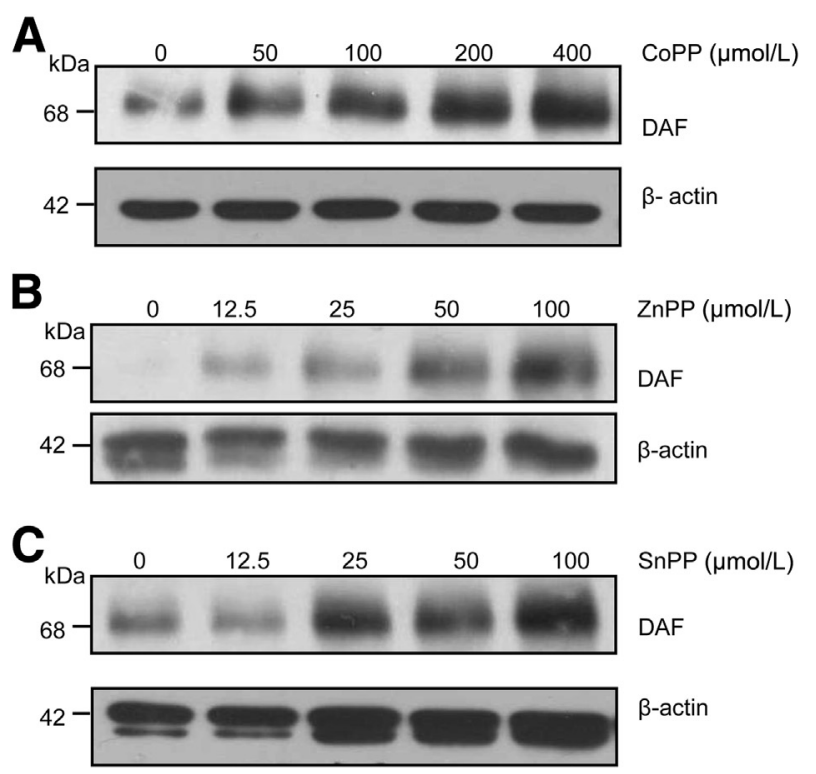

D
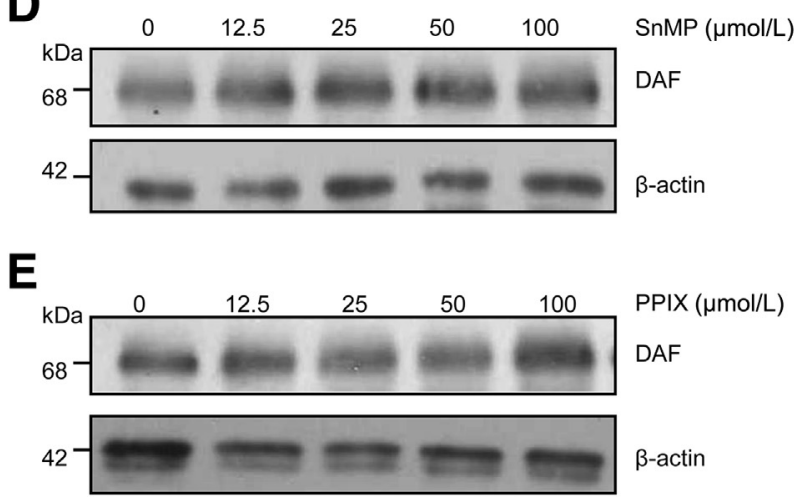

Figure 8 Effect of non-Fe hemin analogues on glomerular decay accelerating factor (DAF). Glomeruli were incubated with increasing concentrations of cobalt protoporphyrin (CoPP; 50 to $400 \mu \mathrm{mol} / \mathrm{L})(A)$, zinc protoporphyrin (ZnPP; 12.5 to $100 \mu \mathrm{mol} / \mathrm{L})(\mathbf{B})$, tin protoporphyrin (SnPP; 12.5 to $100 \mu \mathrm{mol} / \mathrm{L})(\mathbf{C})$, tin mesoporphyrin (SnMP; 12.5 to $100 \mu \mathrm{mol} / \mathrm{L}$ ) (D), or protoporphyrin IX (PPIX; 12.5 to $100 \mu \mathrm{mol} / \mathrm{L}$ ) (E) for 18 hours. Total protein lysates were analyzed by Western blot analysis for DAF expression. $\beta$-Actin was used as a loading control. Representative Western blots are shown. $n=3$ independent experiments.

undergoes heavy glycosylation. During these posttranslational processes, the gpi-DAF protein complex is transported across, or stored in, various cell compartments until it reaches the cell membrane. Therefore, the detection of gpi-DAF in glomeruli treated with vehicle alone for 18 hours (Figure 7A) likely reflects pre-existing levels of this isoform, while the increase in gpi-DAF observed in response to 18 hours of hemin treatment after blockade of de novo protein synthesis (ie, blockade of both DAF precursor and Hmox-1) by CHX (Figure 7A) suggests that hemin promotes a post-translational process, such as glycosylation, increased transport across the cell, increased stability of the gpi anchor, or reduced loss of membranebound gpi-DAF. 


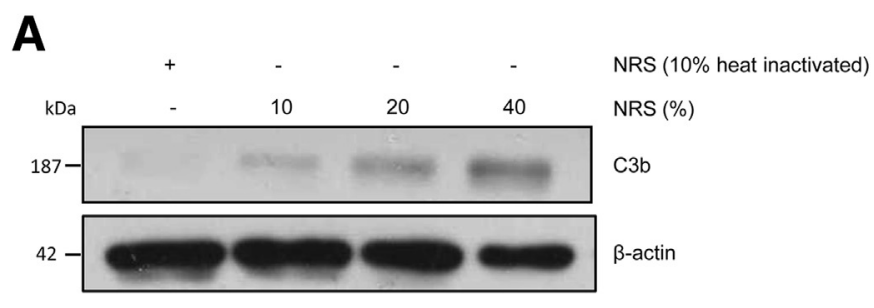

C

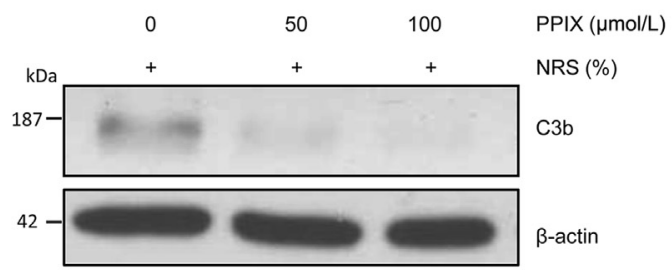

Figure 9 Decay accelerating factor (DAF) induction by tin mesoporphyrin (SnMP) and protoporphyrin IX (PPIX) specifically reduces complement component C3 fragment b (C3b) deposition. A: Wild-type (WT) glomeruli were incubated with either heat inactivated serum or various dilutions of normal rat serum (NRS; $10 \%, 20 \%$, or $40 \%$ ) for 18 hours. Total protein lysates were analyzed by Western blot analysis for C3b protein levels. Representative Western blot from three independent experiments. B: WT glomeruli were incubated in the presence of NRS $(10 \%)$ with increasing concentrations of $\operatorname{SnMP}(50,100 \mu \mathrm{mol} / \mathrm{L})$. C: glomeruli were incubated in the presence of NRS $(10 \%)$ with increasing concentrations of PPIX $(50,100 \mu \mathrm{mol} / \mathrm{L})$ for 18 hours. D: WT glomeruli were isolated and pretreated with the DAF-blocking antibody, RDIII-7, for 15 minutes before treatment with PPIX $(50 \mu \mathrm{mol} / \mathrm{L})$ in the presence of NRS $(10 \%)$ for 18 hours. Total protein lysates were analyzed by Western blot analysis for C3b levels. Representative Western blots are shown. $\beta$-Actin was used as a loading control. Data are expressed as means \pm SEM densitometry values. $n=3$ independent experiments. ${ }^{*} P<0.05$, ${ }^{* * *} P<0.001$ versus NRS only (10\%) (unpaired $t$-test).

The higher potency of noniron hemin analogues or the metal-devoid PPIX with respect to DAF induction (Figure 8) raises the question of whether $\mathrm{Fe}^{2+}$, released via the Hmox reaction when hemin was used as a DAF inducer, suppresses DAF. In this regard, previous work in cultured endothelial cells demonstrated that iron chelation or ferritin overexpression induced DAF. ${ }^{8}$ An alternative explanation is that, in contrast to noniron hemin analogues, which cannot be degraded by HO during 18-hour incubation, hemin is degraded as a result of HO-1 induction. Therefore, hemin concentrations may not be maintained at levels required for sustained DAF induction.

Whether the administration of MPs can attenuate the severity of complement-mediated forms of glomerular injury remains to be determined. In the rat model of anti-GBM antibody-mediated, complement-dependent glomerulonephritis, we previously demonstrated that longterm (2-week) treatment with exogenous hemin (administered s.c.) induced glomerular Hmox-1 and significantly reduced albuminuria and the extent of glomerular lesions. ${ }^{6}$ Human forms of glomerular injury associated with increased $\mathrm{C} 3$ activation and deposition in the absence of

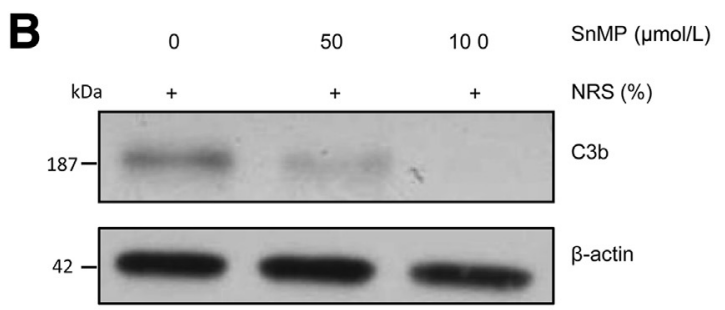

D
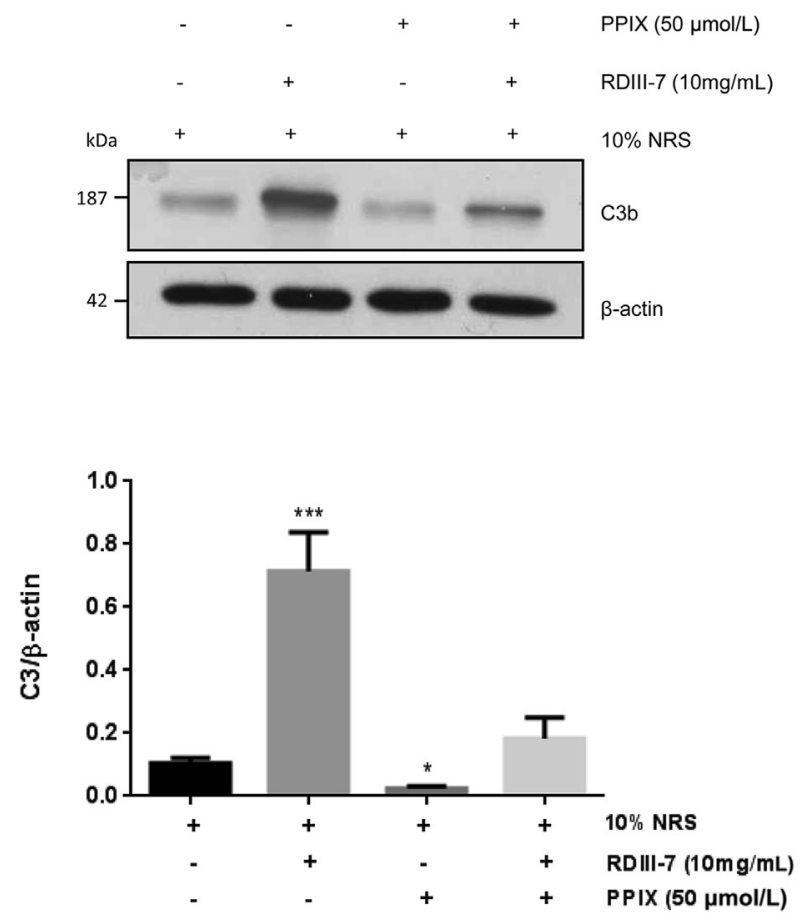

immunoglobulins were recently included in a new clinical entity termed $\mathrm{C} 3$ glomerulopathy. It includes dense deposit disease, membranoproliferative glomerulonephritis, and complement factor $\mathrm{H}-$ related 5 nephropathy. Current treatment of these disorders includes administration of a monoclonal anti-C5 antibody, eculizumab. ${ }^{34,35}$ However, the development of therapeutic strategies upstream of C5 in the complement cascade is also important, as it has been demonstrated that, despite effective antibody-mediated suppression of the terminal complement cascade after the neutralization of $\mathrm{C} 5$, persistent $\mathrm{C} 3$-convertase activity can lead to disease progression. ${ }^{36}$ Furthermore, reduced C3 deposition by up-regulation of key controller proteins such as DAF and/or complement receptor 1-related protein Y was also shown to inhibit $\mathrm{C} 5$ activation. ${ }^{37}$ In this respect, a promising anti-C3 agent, compstatin, has recently emerged, ${ }^{38}$ opening new therapeutic strategies against complement-mediated diseases. A number of the MPs used in the present study are currently used in clinical practice. Hemin, in the form of i.v. hematin, is used in the treatment of acute intermittent porphyria, ${ }^{39}$ while tin protoporphyrin has been used for the treatment of hypebilirubinemic 
syndromes such as neonatal jaundice and primary biliary cirrhosis, with minimal adverse effects. ${ }^{40-42}$ Finally, SnMP is currently being tested in an ongoing clinical trial for use in the treatment of neonatal jaundice. ${ }^{42}$

In summary, the present study establishes Hmox-1 as a regulator of functional DAF in the rat glomerulus capable of minimizing $\mathrm{C} 3$ deposition and the extent of complementdependent injury. Furthermore, it identifies the natural HO substrate hemin and noniron MPs as glomerular DAF inducers capable of reducing $\mathrm{C} 3$ deposition.

\section{Acknowledgment}

We thank Zoe Kolia for technical assistance with animal work.

\section{Supplemental Data}

Supplemental material for this article can be found at http://dx.doi.org/10.1016/j.ajpath.2016.07.009.

\section{References}

1. Pickering MC, D'Agati VD, Nester CM, Smith RJ, Haas M, Appel GB, Alpers CE, Bajema IM, Bedrosian C, Braun M, Doyle M, Fakhouri F, Fervenza FC, Fogo AB, Fremeaux-Bacchi V, Gale DP, Goicoechea de Jorge E, Griffin G, Harris CL, Holers VM, Johnson S, Lavin PJ, Medjeral-Thomas N, Paul Morgan B, Nast CC, Noel LH, Peters DK, Rodriguez de Cordoba S, Servais A, Sethi S, Song WC, Tamburini P, Thurman JM, Zavros M, Cook HT: C3 glomerulopathy: consensus report. Kidney Int 2013, 84:1079-1089

2. Quigg RJ, Nicholson-Weller A, Cybulsky AV, Badalamenti J, Salant DJ: Decay accelerating factor regulates complement activation on glomerular epithelial cells. J Immunol 1989, 142:877-882

3. Lin F, Emancipator SN, Salant DJ, Medof ME: Decay-accelerating factor confers protection against complement-mediated podocyte injury in acute nephrotoxic nephritis. Lab Invest 2002, 82:563-569

4. Sogabe H, Nangaku M, Ishibashi Y, Wada T, Fujita T, Sun X, Miwa T, Madaio MP, Song WC: Increased susceptibility of decay-accelerating factor deficient mice to anti-glomerular basement membrane glomerulonephritis. J Immunol 2001, 167:2791-2797

5. Bao L, Haas M, Minto AW, Quigg RJ: Decay-accelerating factor but not CD59 limits experimental immune-complex glomerulonephritis. Lab Invest 2007, 87:357-364

6. Datta PK, Duann P, Lianos EA: Long-term effect of heme oxygenase (HO)-1 induction in glomerular immune injury. J Lab Clin Med 2006, 147:150-155

7. Duann P, Lianos EA: GEC-targeted HO-1 expression reduces proteinuria in glomerular immune injury. Am J Physiol Renal Physiol 2009, 297:F629-F638

8. Kinderlerer AR, Pombo Gregoire I, Hamdulay SS, Ali F, Steinberg R, Silva G, Ali N, Wang B, Haskard DO, Soares MP, Mason JC: Heme oxygenase-1 expression enhances vascular endothelial resistance to complement-mediated injury through induction of decay-accelerating factor: a role for increased bilirubin and ferritin. Blood 2009, 113:1598-1607

9. Bao L, Spiller OB, St John PL, Haas M, Hack BK, Ren G, Cunningham PN, Doshi M, Abrahamson DR, Morgan BP, Quigg RJ: Decay-accelerating factor expression in the rat kidney is restricted to the apical surface of podocytes. Kidney Int 2002, 62:2010-2021

10. Committee for the Update of the Guide for the Care and Use of Laboratory AnimalsNational Research Council: Guide for the Care and
Use of Laboratory Animals: Eighth Edition. Washington, DC, National Academies Press, 2011

11. Geurts AM, Cost GJ, Remy S, Cui X, Tesson L, Usal C, Menoret S, Jacob HJ, Anegon I, Buelow R: Generation of gene-specific mutated rats using zinc-finger nucleases. Methods Mol Biol 2010, 597:211-225

12. Poss KD, Tonegawa $\mathrm{S}$ : Heme oxygenase 1 is required for mammalian iron reutilization. Proc Natl Acad Sci U S A 1997, 94: 10919-10924

13. Detsika MG, Duann P, Lianos EA: HO-1 expression control in the rat glomerulus. Biochem Biophys Res Commun 2015, 460:786-792

14. Katter K, Geurts AM, Hoffmann O, Mates L, Landa V, Hiripi L, Moreno C, Lazar J, Bashir S, Zidek V, Popova E, Jerchow B, Becker K, Devaraj A, Walter I, Grzybowksi M, Corbett M, Filho AR, Hodges MR, Bader M, Ivics Z, Jacob HJ, Pravenec M, Bosze Z, Rulicke T, Izsvak Z: Transposon-mediated transgenesis, transgenic rescue, and tissue-specific gene expression in rodents and rabbits. FASEB J 2013, 27:930-941

15. Wiggins JE, Patel SR, Shedden KA, Goyal M, Wharram BL, Martini S, Kretzler M, Wiggins RC: NFkappaB promotes inflammation, coagulation, and fibrosis in the aging glomerulus. J Am Soc Nephrol 2010, 21:587-597

16. Glagov S, Zarins C, Giddens DP, Ku DN: Hemodynamics and atherosclerosis. Insights and perspectives gained from studies of human arteries. Arch Pathol Lab Med 1988, 112:1018-1031

17. Dennery PA, Sridhar KJ, Lee CS, Wong HE, Shokoohi V, Rodgers PA, Spitz DR: Heme oxygenase-mediated resistance to oxygen toxicity in hamster fibroblasts. J Biol Chem 1997, 272: 14937-14942

18. Drechsler Y, Dolganiuc A, Norkina O, Romics L, Li W, Kodys K, Bach FH, Mandrekar P, Szabo G: Heme oxygenase-1 mediates the anti-inflammatory effects of acute alcohol on IL-10 induction involving p38 MAPK activation in monocytes. J Immunol 2006, 177: 2592-2600

19. Ye J, Laychock SG: A protective role for heme oxygenase expression in pancreatic islets exposed to interleukin-1beta. Endocrinology 1998 , 139:4155-4163

20. Abate A, Zhao H, Wong RJ, Stevenson DK: The role of Bach1 in the induction of heme oxygenase by tin mesoporphyrin. Biochem Biophys Res Commun 2007, 354:757-763

21. Vreman HJ, Ekstrand BC, Stevenson DK: Selection of metalloporphyrin heme oxygenase inhibitors based on potency and photoreactivity. Pediatr Res 1993, 33:195-200

22. Sassa S: Why heme needs to be degraded to iron, biliverdin IXalpha, and carbon monoxide? Antioxid Redox Signal 2004, 6:819-824

23. Pawluczkowycz AW, Lindorfer MA, Waitumbi JN, Taylor RP: Hematin promotes complement alternative pathway-mediated deposition of $\mathrm{C} 3$ activation fragments on human erythrocytes: potential implications for the pathogenesis of anemia in malaria. J Immunol 2007, 179: $5543-5552$

24. Hori R, Kashiba M, Toma T, Yachie A, Goda N, Makino N, Soejima A, Nagasawa T, Nakabayashi K, Suematsu M: Gene transfection of H25A mutant heme oxygenase-1 protects cells against hydroperoxide-induced cytotoxicity. J Biol Chem 2002, 277:10712-10718

25. Ni L, Saleem M, Mathieson PW: Podocyte culture: tricks of the trade. Nephrology 2012, 17:525-531

26. Dileepan KN, Sharma R, Stechschulte DJ, Savin VJ: Effect of superoxide exposure on albumin permeability of isolated rat glomeruli. J Lab Clin Med 1993, 121:797-804

27. Quigg RJ, Galishoff ML, Sneed AE 3rd, Kim D: Isolation and characterization of complement receptor type 1 from rat glomerular epithelial cells. Kidney Int 1993, 43:730-736

28. Yoshinaga T, Sassa S, Kappas A: Purification and properties of bovine spleen heme oxygenase. Amino acid composition and sites of action of inhibitors of heme oxidation. J Biol Chem 1982, 257: $7778-7785$

29. Haider A, Olszanecki R, Gryglewski R, Schwartzman ML, Lianos E, Kappas A, Nasjletti A, Abraham NG: Regulation of cyclooxygenase 
by the heme-heme oxygenase system in microvessel endothelial cells. J Pharmacol Exp Ther 2002, 300:188-194

30. Datta PK, Gross EJ, Lianos EA: Interactions between inducible nitric oxide synthase and heme oxygenase-1 in glomerulonephritis. Kidney Int 2002, 61:847-850

31. Banadakoppa M, Liebenthal D, Nowak DE, Urvil P, Yallampalli U, Wilson GM, Kishor A, Yallampalli C: Role of transcription factor Sp1 and RNA binding protein $\mathrm{HuR}$ in the downregulation of $\mathrm{Dr}+$ Escherichia coli receptor protein decay accelerating factor (DAF or CD55) by nitric oxide. FEBS J 2013, 280:840-854

32. Andrade BB, Araujo-Santos T, Luz NF, Khouri R, Bozza MT, Camargo LM, Barral A, Borges VM, Barral-Netto M: Heme impairs prostaglandin E2 and TGF-beta production by human mononuclear cells via $\mathrm{Cu} / \mathrm{Zn}$ superoxide dismutase: insight into the pathogenesis of severe malaria. J Immunol 2010, 185:1196-1204

33. Shao J, Yang VW, Sheng H: Prostaglandin E2 and Kruppel-like transcription factors synergistically induce the expression of decay-accelerating factor in intestinal epithelial cells. Immunology 2008, 125:397-407

34. Le Quintrec M, Lionet A, Kandel C, Bourdon F, Gnemmi V, Colombat M, Goujon JM, Fremeaux-Bacchi V, Fakhouri F: Eculizumab for treatment of rapidly progressive C3 glomerulopathy. Am J Kidney Dis 2015, 65:484-489

35. Payette A, Patey N, Dragon-Durey MA, Fremeaux-Bacchi V, Le Deist F, Lapeyraque AL: A case of C3 glomerulonephritis successfully treated with eculizumab. Pediatr Nephrol 2015, 30:1033-1037
36. Gurkan S, Fyfe B, Weiss L, Xiao X, Zhang Y, Smith RJ: Eculizumab and recurrent C3 glomerulonephritis. Pediatr Nephrol 2013, 28: 1975-1981

37. Quigg RJ, Holers VM, Morgan BP, Sneed AE 3rd: Crry and CD59 regulate complement in rat glomerular epithelial cells and are inhibited by the nephritogenic antibody of passive Heymann nephritis. J Immunol 1995, 154:3437-3443

38. Mastellos DC, Yancopoulou D, Kokkinos P, Huber-Lang M, Hajishengallis G, Biglarnia AR, Lupu F, Nilsson B, Risitano AM, Ricklin D, Lambris JD: Compstatin: a C3-targeted complement inhibitor reaching its prime for bedside intervention. Eur J Clin Invest 2015, 45:423-440

39. Anderson KE, Bloomer JR, Bonkovsky HL, Kushner JP, Pierach CA, Pimstone NR, Desnick RJ: Recommendations for the diagnosis and treatment of the acute porphyrias. Ann Intern Med 2005, 142: $439-450$

40. Anderson KE, Simionatto CS, Drummond GS, Kappas A: Disposition of tin-protoporphyrin and suppression of hyperbilirubinemia in humans. Clin Pharmacol Ther 1986, 39:510-520

41. Berglund L, Angelin B, Hultcrantz R, Einarsson K, Emtestam L, Drummond G, Kappas A: Studies with the haeme oxygenase inhibitor Sn-protoporphyrin in patients with primary biliary cirrhosis and idiopathic haemochromatosis. Gut 1990, 31:899-904

42. Schulz S, Wong RJ, Vreman HJ, Stevenson DK: Metalloporphyrins-an update. Front Pharmacol 2012, 3:68 